\title{
Artocarpus altilis and Pandanus tectorius: Two important fruits of Oceania with medicinal values
}

\author{
Shigeyuki Baba1, Hung Tuck Chan', Mio Kezuka', Tomomi Inoue ${ }^{2}$, Eric Wei Chiang Chan ${ }^{3 *}$ \\ ${ }^{1}$ Secretariat, International Society for Mangrove Ecosystems (ISME), Faculty of Agriculture, University of the Ryukyus, Okinawa, 903-0129 \\ Japan, ${ }^{2}$ Centre for Environmental Biology and Ecosystem Studies, National Institute for Environmental Studies, Onogawa, Tsukuba 305-0053, \\ Japan, ${ }^{3}$ Faculty of Applied Sciences, UCSI University, 56000 Cheras, Kuala Lumpur, Malaysia
}

\section{A B S T R A C T}

\begin{abstract}
Artocarpus altilis (breadfruit) and Pandanus tectorius (screw pine) are two cultural icons of Oceania. Fruits of both species are rich in carbohydrates, and contain proteins, vitamins and minerals. Endowed with triterpenes, flavonoids, stilbenes, arylbenzofurans and sterols as chemical constituents, fruits of $A$. altilis possess antioxidant, antimicrobial, anticancer and anti-hyperglycemic properties. With phenolic compounds such as flavonoids and caffeoylquinic acids, fruits of $P$. tectorius possess antioxidant, antibacterial, anti-diabetic, $\alpha$-glucosidase inhibitory and antidiarrheal properties. In comparison, more bioactivities have been reported in other plant parts such as leaves, bark, wood and root of these two species. Nevertheless, the scientific evidence is convincing that the regular consumption of fruits of $A$. altilis and $P$. tectorius by the islanders of the Pacific does have both nutritive and medicinal values.
\end{abstract}

Keywords: Breadfruit; Screw pine; Phytochemistry; Pharmacology

\section{INTRODUCTION}

Inspired by the books The Fruits We Eat (SPC, 2001), Fruits of Oceania (Walter and Sam, 2002) and Gardens of Oceania (Walter and Lebot, 2007), and by our regular visits to Kiribati, Fiji, Tuvalu and Samoa in the past decade, we opted to review the medicinal properties of fruits of Artocarpus altilis and Pandanus tectorius. They are two important fruit crops that are cultural icons of Oceania (Melanesia, Micronesia and Polynesia). Other major fruit crops include avocado, banana, plantain, citrus, coconut, mango, papaya and pineapple (SPC, 2001).

Grown in 86 countries worldwide, $A$. altilis is an important staple crop in Oceania that has been cultivated for more than 3000 years (Ragone, 2006, 2011). Islanders have selected, grown and named hundreds of cultivars that can be distinguished by their fruits (shape, size, weight, seasonality, skin texture, flesh colour and presence or absence of seeds) and leaves (shape, size and colour). In Vanuatu alone, more than 500 cultivars of $A$. altilis have been identified (Labouisse, 2016).
In the Pacific, the different varieties of $P$. tectorius are identified by their appearance, and the size, shape and colour of fruit bunches and individual phalanges (SPC, 2001). Other features include flavour, water content and ease of detachment from the bunch. In the Marshall Islands, some 150 indigenous varieties of $P$. tectorius have been identified. About 60 varieties have been reported in the Federated States of Micronesia (Englberger et al., 2003a).

To date, there are at least six reviews on $A$. altilis (Ragone, 2006; Deivanai and Subhash, 2010; Jones et al., 2011; Sikarwar et al., 2014; Mohanty and Pradhan, 2015; Turi et al., 2015) and three reviews on P. tectorius (Thomson et al., 2006; Lim, 2012; Adkar and Bhaskar, 2014). Breadfruit has also been reviewed under the genus Artocarpus (Hakim, 2010; Jagtap and Bapat, 2010; Hari et al., 2014). These reviews entail the botany, ecology, silviculture, uses, phytochemistry and pharmacology of $A$. altilis and $P$. tectorius. Unlike previous articles that describe all plant parts, this review focuses on the phytochemistry and pharmacology of the edible fruits of $A$. altilis and P. tectorius.

\footnotetext{
*Corresponding author:

Eric Wei Chiang Chan, Faculty of Applied Sciences, UCSI University, 56000 Cheras, Kuala Lumpur, Malaysia

E-mail: chanwc@ucsiuniversity.edu.my; erchan@yahoo.com
}

Received: 28 February 2016

Revised: 13 May 2016;

Accepted: 14 May 2016;

Published Online: 24 May 2016 


\section{ARTOCARPUS ALTILIS}

\section{Botany and uses}

Artocarpus altilis (Parkinson) Fosberg (breadfruit) belongs to the family Moraceae. Synonyms of $A$. altilis are A. communis and A. incisus (The Plant List, 2013a). In Oceania, the tree is deciduous, fast-growing and can reach heights of 12-15 m (Ragone, 2006, 2011). All parts of the tree produce white latex. The bark is greyish and the trunk can grow to $30-100 \mathrm{~cm}$ in diameter, often with buttresses. Leaves are alternate, thick, leathery, and can range from almost entire to deeply dissected, with a pointed apex (Fig. 1). The upper leaf surface is dark green with distinct yellowish veins. The species is monoecious with male and female inflorescences present on the same tree. Male inflorescences are elongated and club-shaped while female inflorescences are rounded. They each consist of a spongy core with many tiny flowers. Trees start to bear fruits after 3-5 years. Fruits are compound, round or oval with a greenish-yellow skin, patterned with hexagonal markings. Depending on the variety, the flesh is creamy white or pale yellow, seedless or containing many seeds. Seedless cultivars are common in Micronesia and Polynesia. Seeds are brown, shiny, rounded, irregularly compressed. Propagation is by raising basal shoots or root cuttings.

Breadfruit is an important staple food that is eaten raw, boiled, steamed or roasted (Ragone, 2006, 2011; Labouisse, 2016). Most of the trees are grown for subsistence with small quantities of the fruits sold in town markets. Fruits generally weigh $1-2 \mathrm{~kg}$ and the edible portion is $70-75 \%$ of the fruit (Jones et al., 2011). Edible and dry weight fruit yields of $6 \mathrm{t} /$ ha have been reported.

In Oceania, the light hardwood of $A$. altilis is used for building houses and canoes, and is often carved into ornaments and utensils (Ragone, 2011; Labouisse, 2016). Old trees are felled for firewood. The inner bark was formerly used to make bark cloth (tapa). Leaves are used to wrap food for cooking in a pit stove with heated rocks. The latex has been used as chewing gum and adhesive. Dried male flowers can be burned in the evening to distract mosquitoes and other insects (Jones et al., 2012).

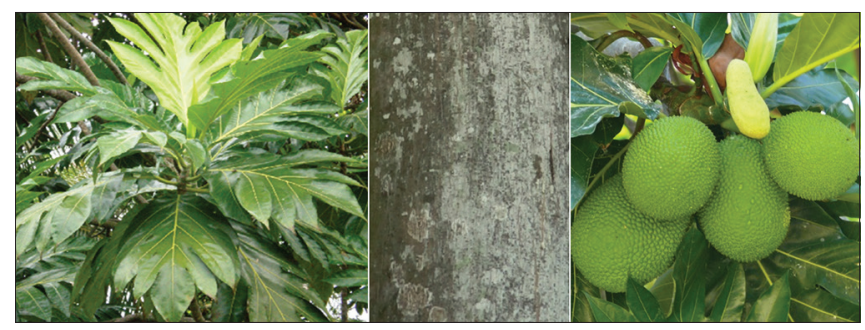

Fig 1. Leaves (left), bark (middle) and fruits (right) of Artocarpus altilis.
Islanders use the latex of $A$. altilis to treat skin diseases, stomach ache, diarrhoea and dysentery (Ragone, 2006). Crushed leaves are used to treat skin, ear and eye infections. Other medicinal uses include the roots as stringent, purgative and poultice for skin ailments, and the bark for treating headache.

\section{Nutrient content of fruits}

Fruits of breadfruit are nutritious and are consumed as starchy staple when mature (Ragone, 2006, 2011). They are rich in carbohydrates, and contain vitamins and minerals. A fruit quality evaluation of 20 breadfruit cultivars sampled from the National Tropical Botanical Garden in Hawaii showed significant differences in aroma, texture, colour, flavour, sweetness, starchiness, moistness, stringiness and firmness (Ragone and Cavaletto, 2006). The greatest differences were in colour and texture. Nutrient analyses showed that the pulp of mature fruits of $A$. altilis (100 g) contained 69\% of water, $1.0 \mathrm{~g}$ of protein, $29 \mathrm{~g}$ of carbohydrate, $5.2 \mathrm{~g}$ of dietary fibre, $22 \mathrm{mg}$ of sodium, $24 \mathrm{mg}$ of magnesium, $32 \mathrm{mg}$ of phosphorous, $350 \mathrm{mg}$ of potassium and $20 \mathrm{mg}$ of calcium on the average. The content of vitamin $\mathrm{C}$, $\beta$-carotene and lutein was $3.8 \mathrm{mg}, 13 \mu \mathrm{g}$ and $72 \mu \mathrm{g}$, respectively. Breadfruit is a good source of vitamin C, thiamin, riboflavin and niacin (Englberger et al., 2003a). Nutritionally, breadfruit is comparable or superior to other staple food commonly consumed in Oceania e.g., taro, plantain, cassava, sweet potato and rice (Dignan et al., 2004).

\section{Phytochemistry and pharmacology of fruits}

Early chemical analysis of fruits of $A$. altilis led to the isolation of triterpenes of cycloartenol, cycloart-23-ene$3 \beta, 25$-diol, cycloart-25-ene-3 $\beta, 24$-diol and $\alpha$-amyrin (Altman and Zito, 1976). Volatile chemicals of fresh and cooked fruits of $A$. altilis have been studied (Iwaoka et al., 1994). In fresh breadfruit, 40 volatile compounds were identified with cis-3-hexenol (36\%) being the major constituent. Out of 43 volatile compounds identified in breadfruit boiled for $10 \mathrm{~min}$, the main component was ethyl acetate (38\%). From the methanol and ethyl acetate fruit extracts of $A$. altilis, arylbenzofuran of moracin M; stilbenes of oxyresveratrol and artoindonesianin F; flavonoids of norartocarpanone, norartocarpetin and isoartocarpesin; triterpenes of $3 \beta$-acetoxyolean-12-en-11-one and cycloartenyl acetate; and sterols of sitosterol $\beta$-D-glucopyranoside and sitosterol have been isolated (Amarasinghe et al., 2008).

Fruits of $A$. altilis have been reported to possess antioxidant and antimicrobial activities. A comparative study has been conducted on the antioxidant properties of the pulp, peel and whole fruit of $A$. altilis extracted with hexane, dichloromethane and methanol (Jalal et al., 2015). Results 
showed that the highest values were from the methanol pulp extract with total phenolic content of $780 \mathrm{mg} \mathrm{GAE} / \mathrm{g}$, total flavonoid content of $6210 \mathrm{mg}$ QE/g, DPPH radical scavenging $\mathrm{IC}_{50}$ of $55 \mu \mathrm{g} / \mathrm{ml}$ and $\beta$-carotene bleaching ability of $88 \%$. Against pathogenic microorganisms of Staphylococcus aureus, Staphylococcus epidermidis, Bacillus cereus, Salmonella typhimurium, Escherichia coli, Klebsiella pneumonia and Candida albicans, the methanol fruit pulp extract of $A$. altilis had the largest zone of inhibition and the lowest minimum inhibitory concentration (MIC). The methanol and ethyl acetate fruit extracts against $S$. aureus, Psendomonas aeruginosa, Streptococcus mutans and Enterococcus faecalis (Pradhan et al., 2013). MIC values of the methanol fruit extract were $0.9 \mathrm{mg}$ for $S$. aureus and $S$. mutans, and $0.6 \mathrm{mg}$ for E. faecalis. The ethyl acetate fruit extract inhibited $S$. aureus, $P$. aeruginosa and E. faecalis with MIC values of $0.6 \mathrm{mg}, 0.9 \mathrm{mg}$ and $1.2 \mathrm{mg}$, respectively.

From the methanol fruit extract of $A$. altilis, two new geranyl flavonoid derivatives together with four known compounds were isolated (Hsu et al., 2011). They were arcommunol A [1], arcommunol B [2], lespeol [3], 3'-geranyl-2',3,4,4'tetrahydroxychalcone [4], xanthoangelol [5] and 8-geranyl3',4',7-trihydroxyflavone [6]. When tested against a panel of human cancer cells based on inhibitory activity $\left(\mathrm{IC}_{50}\right)$, strongest inhibition was displayed by [1] against SKHep-1 cells $(2.1 \mu \mathrm{M})$, by [4] against Hep3B $(7.8 \mu \mathrm{M})$, and by [6] against HepG2 $(4.4 \mu \mathrm{M})$ and PLC5 $(9.2 \mu \mathrm{M})$ cells. Against SK-Hep-1 cells, [1] induced apoptosis possibly through up-regulation of p53, death-receptor signalling, loss of mitochondrial trans-membrane potential, followed by activation of caspases.

Fruits of $A$. altilis have been reported to possess antihyperglycemic properties. The hypoglycemic effects of the aqueous fruit extract and powder were demonstrated via the inhibitory activity of $\alpha$-amylase, $\alpha$-glucosidase and sucrase, and by the enhancement of glucose uptake by yeast cells (Sairam and Urooj, 2013). Values were however not as strong as those of leaf and bark extracts. The possible mode of action of $A$. altilis as a hypoglycemic agent against diabetes is by glucose adsorption, carbohydrate metabolizing enzyme inhibition and glucose diffusion facilitation through the cell membrane.

A geranyl flavonoid derivative (5,7,4'-trihydroxy-6geranylflavanone) isolated from fruits of $A$. altilis was reported to possess anti-inflammatory properties (Lin et al., 2011). The compound attenuated S100B-induced inflammatory response in human monocytes by decreasing reactive oxygen species and pro-inflammatory cytokines, and by inhibiting advanced glycation end-products (RAGE)-dependent signalling.
In comparison to fruits, more bioactivities have been reported in the other plant parts of $A$. altilis (Table 1$)$. Leaves possess properties which include anti-inflammatory, anti-atherosclerotic, cytotoxic, hypotensive, skin lightening, hypoglycemic, anti-malarial, renal improvement and hedgehog signalling inhibitory activities. The bark has been reported to be antioxidative, antimicrobial, anti-atherogenic, hypocholestrolemic, hypoglycemic, hepatoprotective, arginase inhibitory and renal protective. The heartwood possesses depigmenting, anti-tyrosinase and anticancer properties while antioxidant, antiplatelet, antitubercular, antiplasmodial, anticancer and UV protective activities have been reported in the root cortex.

\section{PANDANUS TECTORIUS}

\section{Botany and uses}

Pandanus tectorius Parkinson ex Du Roi (screw pine or beach pandan) belongs to the family Pandanaceae. Previously treated as a distinct species, Pandanus odoratissimus L. is now a synonym of $P$. tectorius (The Plant List, 2013b). Growing up to $15 \mathrm{~m}$ in height, $P$. tectorius is a stout, branching and multi-stemmed plant (Thomson et al., 2006). Stems are greyish- or reddish-brown, smooth or flaky, ringed by leaf scars and produce prop roots at the base. Leaves are spirally arranged in three rows, sword-like with spiny margins and midribs, and apices with flagella. In the afternoon, plants have a characteristic drooping appearance with the leaves hanging downwards. The species is dioecious with male and female flowers occurring in separate plants. Male flowers are tiny, pendulous and fragrant with white spathes. Female flowers are single spikes with yellow spathes. Resembling pineapples, fruits are globular and contain tightly bunched, wedge-shaped fleshy keys (Fig. 2). They are green when young turning orange-red when ripe. Seeds are obovoid, ellipsoid, or oblong, reddish-brown outside and whitish gelatinous inside. Propagation is by raising branch cuttings.

The distribution of $P$. tectorius stretches from the coast of South and Southeast Asia eastward through Papua New Guinea and tropical northern Australia, and extends into the Pacific islands of Oceania (Lim, 2012). In Oceania, P. tectorius is an important fruit crop that occurs in Marshall Islands, Kiribati, Papua New Guinea, New Caledonia, Fiji and most of Polynesia (SPC, 2001).

Throughout the Pacific, the fleshy fruit keys of P. tectorius are consumed fresh or processed into various preserved foods (Thomson et al., 2006). Fruits are green when young, turning to yellow and then orange or orange-red when mature. Pandanus fruits can be eaten when the green heads of the keys separate out, displaying the bright orange colour and emitting a characteristic sweet smell (Fig. 2). The fibrous and fleshy basal mesocarp is the portion of the key 
Table 1: Bioactivities of other plant parts of Artocarpus altilis

\begin{tabular}{|c|c|}
\hline Plant part and bioactivity & Reference \\
\hline \multicolumn{2}{|l|}{ Leaf } \\
\hline Flavonoids with anti-inflammatory properties & Wei et al. (2005) \\
\hline Phytochemicals with anti-atherosclerotic properties & Wang et al. (2006) \\
\hline Cytotoxic activity against murine P-388 leukaemia cells & Lotulung et al. (2008) \\
\hline Cytotoxic effects of new geranyl chalcone derivatives against SW 872 & Fang et al. (2008) \\
\hline human liposarcoma cells & Hsu et al. (2012) \\
\hline Anti-inflammatory activity of isolated geranyl flavonoid derivatives & Nwokocha et al. (2012) \\
\hline Hypotensive effects on rats & Rao et al. (2013) \\
\hline Skin lightening activity by inhibition of melanocyte dendrite elongation & Sairam and Urooj (2013) \\
\hline In-vitro and ex-vivo hypoglycemic activity & Arai et al. (2015) \\
\hline Hedgehog signalling pathway inhibition & Fakhrudin et al. (2015) \\
\hline Anti-inflammatory effect on carrageenan-induced paw oedema in rats & Nguyen et al. (2014) \\
\hline Cytotoxic activity of the extract and isolated compounds against human PANC-1 pancreatic cancer cells & Mozef et al. (2015) \\
\hline Protective effect against atherosclerosis & Jeon et al. (2015) \\
\hline Extract and geranyl dihydrochalcone inhibited STAT3 activity in prostate cancer DU145 cells & Hafid et al. (2016) \\
\hline Good to moderate in-vitro and in-vivo antimalarial activity against & Safitri et al. (2016) \\
\hline \multicolumn{2}{|l|}{ Plasmodium falciparum and $P$. berghei } \\
\hline \multicolumn{2}{|l|}{ Improves kidney function in rats with renal failure } \\
\hline \multicolumn{2}{|l|}{ Bark } \\
\hline Hypoglycemic effect of the root bark on STZ-treated diabetic rats & $\begin{array}{l}\text { Adewole and Ojewole } \\
\text { (2007a, 2007b) }\end{array}$ \\
\hline Antimicrobial activity of the stem bark extract and isolated compounds & Kuete et al. (2011) \\
\hline In-vitro and ex-vivo hypoglycemic activity & Sairam and Urooj (2013) \\
\hline Anti-atherogenic and hypocholestrolemic activities of the stem bark in hypercholestrolemic rats & Adaramoye and Akanni (2014) \\
\hline Antioxidative and arginase inhibitory activities of the stem bark & Akanni et al. (2014) \\
\hline Protective effect of the stem bark against Cd-induced liver and kidney dysfunction in rats & Adaramoye and Akanni (2016) \\
\hline \multicolumn{2}{|l|}{ Heartwood } \\
\hline Compounds isolated from the heartwood with inhibitory effects on & Shimizu et al. $(1998,2000)$ \\
\hline $5 \alpha$-reductase and melanin biosynthesis & Donsing et al. (2008) \\
\hline Melanogenesis and tyrosinase inhibitory activities of the heartwood & Arung et al. (2009) \\
\hline extract and isolated atrocarpin & Buranajaree et al. (2011) \\
\hline Anticancer activity by inducing sub-G1 apoptosis in human T47D & Lan et al. (2013) \\
\hline breast cancer cells & Tzeng et al. (2014) \\
\hline Depigmenting effects of the heartwood on UVB-induced hyper- & Fu et al. (2014) \\
\hline pigmentation in C57BL/6 mice & Tiraravesit et al. (2015) \\
\hline \multicolumn{2}{|l|}{$\begin{array}{l}\text { Antioxidant and anti-tyrosinase activities, and inhibition of melanin } \\
\text { production of isolated prenylated flavonoids isolated from heartwood }\end{array}$} \\
\hline \multicolumn{2}{|l|}{$\begin{array}{l}\text { Anticancer activity toward human HepG2 and PLC/PRF/5 hepatoma cancer cells of the heartwood } \\
\text { extract and fractions rich in artocarpin }\end{array}$} \\
\hline \multicolumn{2}{|l|}{ Heartwood extract inhibits melanogenesis through activation of ERK and JNK signalling pathways } \\
\hline \multicolumn{2}{|l|}{ Protective effect of the heartwood on UVB-exposed skin in mice } \\
\hline \multicolumn{2}{|l|}{ Root cortex } \\
\hline Antiplatelet effect of flavonoids isolated from the root cortex on human platelet-rich plasma & Weng et al. (2006) \\
\hline Antitubercular, antiplasmodial and anticancer activities & Boonphong et al. (2007) \\
\hline Antioxidant activity of prenylflavonoids isolated from the root cortex & Lin et al. (2009) \\
\hline $\begin{array}{l}\text { Attenuation of UVA-induced damaged human keratinocytes and fibroblasts by prenylated phenols } \\
\text { isolated from the root cortex }\end{array}$ & Lin et al. (2015) \\
\hline
\end{tabular}

that is chewed and eaten. In Micronesia, adults consume more than 20 fresh keys daily during the fruiting season. Chewing fresh keys between meals is a pleasurable and highly social activity.

Not all fruits are edible with some cultivars having oxalate crystals, which cause mouth irritation (Thomson et al.,
2006). Fruits of different varieties are distinct in size, shape, colour, flavour and juiciness. They are rich in vitamin C and carotenoids, including $\beta$-carotene (Dignan et al., 2004; Englberger et al., 2003a). Varieties with soft keys can be eaten raw while those with fibrous keys are processed into paste and flour before consumption or sold as chips (SPC, 2001; Ragone, 2011). 


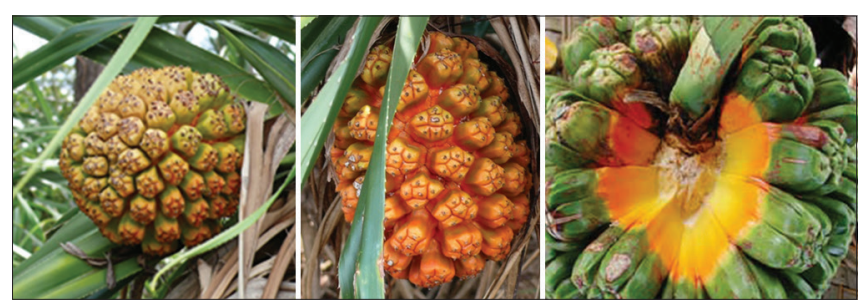

Fig 2. Yellow (left) and orange (middle) fruits, and fruit keys (right) of Pandanus tectorius. The photo on fruit keys is from Thomson et al. (2006).

In Oceania, $P$. tectorius is an important source of wood for buildings and crafts (SPC, 2001; Thomson et al., 2006). The dried leaves are used for thatching traditional houses. The green leaves are processed and woven into mats, baskets, fans, hats and other handicrafts. The womenfolk in Marshall Islands are considered the finest weavers known for their quality mats with patterns created by combining natural and dyed strips of leaves (Baba et al., 2013). Elsewhere, the womenfolk of the Mah Meri aboriginal tribe on Carey Island in Selangor, Malaysia are also renowned for their exquisite purses and pouches woven from leaves of P. tectorius.

The species is also an important medicinal plant (Thomson et al., 2006). In Kiribati, the leaves are used as remedy for cold, influenza, hepatitis, dysuria, asthma, boils and cancer, while the roots are used to treat haemorrhoids. In Hawaii, fruits, male flowers and aerial roots are used to treat digestive and respiratory disorders. In Palau, roots and leaves are used to alleviate stomach cramps and vomiting, respectively. Roots are also known for their use in traditional medicine in Pohnpei.

\section{Nutrient content of fruits}

The keys of P. tectorius fruits (100 g) contain 80\% of water, $1.3 \mathrm{~g}$ of protein, $17 \mathrm{~g}$ of carbohydrate, $3.5 \mathrm{~g}$ of dietary fibre, $70 \mathrm{mg}$ of sodium, $17 \mathrm{mg}$ of magnesium, $236 \mathrm{mg}$ of potassium, $88 \mathrm{mg}$ of calcium, $60 \mu \mathrm{g}$ of $\beta$-carotene, $5.0 \mu \mathrm{g}$ of vitamin A and $5.2 \mathrm{mg}$ of vitamin C (Dignan et al., 2004). Five cultivars of $P$. tectorius collected from the Federated States of Micronesia and analysed for $\alpha$ - and $\beta$-carotene showed that cultivars with yellow fruit coloration contained low levels of carotenoids (Englberger et al., 2013b). Cultivars with orange fruits, which are preferred by the islanders, contained higher levels of up to $190 \mathrm{mg} / 100 \mathrm{~g}$ of $\alpha$-carotene and $393 \mathrm{mg} / 100 \mathrm{~g}$ of $\beta$-carotene.

\section{Phytochemistry and pharmacology of fruits}

From the fruit of $P$. tectorius, 15 compounds including 10 phenolic compounds and five flavonoids were isolated for the first time (Zhang et al., 2012). The compounds were vanillin, trans-ethyl caffeate, cis-ethyl caffeate, ethyl coumarate, trans-3,4-dihydroxycinnamaldehyde, sinapaldehyde, dihydroconiferyl alcohol, coniferyl alcohol, 3-hydroxy-1-(4-hydroxy-3-methoxyphenyl)propan-1-one, salicylaldehyde, tangeretin, sakuranetin, chrysin, naringenin and 5,8-dihydroxy-7-methoxy-flavone. Soon after, the same group of scientists isolated two new phenolic compounds, named pandanusphenols A and B (Zhang et al., 2013a). Some of these compounds have been reported to possess useful pharmacological properties. Vanillin is known to be a potent antioxidant and inhibits tyrosinase. Tangeretin and naringenin have cholesterol-lowering ability while ethyl caffeate has anti-inflammatory properties.

From fruits of $P$. tectorius, one new and six known aldehyde compounds were isolated and identified (Mai et al., 2015). They were (Z)-4-hydroxy-3-(4-hydroxy-3-methylbut-2-en1-yl) benzaldehyde, $p$-hydroxybenzaldehyde, syringaldehyde, $(E)$-ferulaldehyde, $(E)$-sinapinaldehyde, vanillin and 5 -hydroxymethylfurfual. When tested for $\alpha$-glucosidase inhibitory activity, the compounds $\left(\mathrm{IC}_{50}\right.$ of 37-192 $\left.\mu \mathrm{M}\right)$ showed better activity than the standard drug of acarbose $\left(\mathrm{IC}_{50}\right.$ of $\left.215 \mu \mathrm{M}\right)$.

Recently, fruits of $P$. tectorius have been reported to be rich in caffeoylquinic acids (CQAs). From the $n$-butanol fraction of the ethanol fruit extract, 15 types of CQAs were identified (Liu et al., 2013; Zhang et al., 2013b). They comprised four CQAs (1-CQA, 3-CQA, 4-CQA and 5-CQA), eight di-CQAs, two methyl esters of di-CQAs and one tri-CQA. Major components were 1,4-CQA, 3,4CQA and 3,5-CQA. Besides antioxidant properties, studies have shown that CQAs display diverse bioactivities such as antimicrobial, anti-inflammatory, analgesic, antipyretic, anti-hyperlipidemia, anti-hyperglycemia, anti-skin aging and cytotoxic properties (Wong et al., 2014).

Analysis of the essential oil extracted from ripe fruits of $P$. tectorius showed that the major components were geranyl acetate (28\%), 3-methyl-3-buten-1-yl cinnamate (17\%), 3-methyl-3-buten-1-yl acetate (10\%) and ethyl cinnamate $(10 \%)$ (Vahirua-Lechet et al., 1996). Major essential oil components of fruits of $\mathrm{P}$. tectorius sampled from Hainan were alkenes of docosene (15\%) and hexacosene $(11 \%)$, and alkanes of 1,2-diethyl-cyclohexa-decane (18\%) and cyclotetracosane (12\%) (Wang et al., 2011).

A study on some bioactivities of the hexane, ethyl acetate and methanol extracts of keys and cores of P. tectorius fruits has been conducted in Malaysia (Adriani et al., 2015). The results showed that the ethyl acetate core extract had the highest phenolic content and antioxidant capacity, while the ethyl acetate key extract displayed the highest antibacterial activity with inhibition zones of $10-15 \mathrm{~mm}$ against Grampositive (Bacillus subtilis and $S$. aureus) and Gram-negative (E. coli and P. aeruginosa) bacteria. All the six extracts did 
not have any cytotoxic activity against selected normal cells (RAW and L-6) and cancer cell lines (HeLa, HepG2 and MCF-7).

Earlier, fruits of P. tectorius have been reported to possess anti-diabetic properties. The anti-hyperlipidemic effects and possible mechanisms of action of the fruit extract on hamsters fed with a high fat-diet were investigated (Zhang et al., 2013b). Administration of the CQA-rich $n$-butanol fraction of the ethanol fruit extract of $P$. tectorius for a month effectively reduced retroperitoneal fat, and serum and hepatic cholesterol and triglycerides. Treatment with the fruit extract significantly stimulated the activity of AMP-activated protein kinase (AMPK) as well as those of serum and hepatic lipoprotein lipase (LPL). The results suggested that the fruit fraction moderated hyperlipidemia and improved the liver lipid profile. These effects were attributed to increasing the expression of peroxisome proliferator-activated receptor alpha (PPAR $\alpha)$ associated genes, and to up-regulating LPL and AMPK activities. Of the CQAs isolated from fruits of $P$. tectorius, the same group of scientists also reported that 3-CQA, 3,4-CQA and 4,5CQA significantly inhibited lipid accumulation and reduced the intracellular content of total cholesterol and triglyceride in HepG2 hepatoma cells (Liu et al., 2013; Wu et al., 2015). The mechanism of actions involves up-regulating the expression of lipid oxidative genes and down-regulating the expression of lipogenic genes.

Further work on the hypoglycemic and hypolipidemic effects of the CQA-rich fraction of the fruit extract of $P$. tectorius was investigated in diabetic $\mathrm{db} / \mathrm{db}$ mice (Wu et al., 2014). Treatment with the extract at $200 \mathrm{mg} / \mathrm{kg}$ significantly reduced body weight and fasting glucose level, and alleviated high blood insulin and hyperlipidemia. The elevated levels of serum pro-inflammatory cytokines and islet hypertrophy in $\mathrm{db} / \mathrm{db}$ mice were markedly attenuated.
Biochemical analysis showed that the extract stimulated AMPK and AS160, and enhanced the expression and translocation of glucose transporter type 4 (GLUT4) in skeletal muscles. Overall, the extract was found to benefit the treatment of diabetes by alleviating hyperglycemia and dyslipidemia via the activation of AMPK-AS160GLUT4 pathway in skeletal muscles, and the inhibition of gluconeogenesis and lipogenesis in the liver.

The antidiarrheal effects of fruits of $P$. tectorius have been reported. Based on defecation, intestinal transit and intestinal fluid accumulation (IFA), antidiarrheal activities were evaluated in rats with castor oil-induced diarrhoea (Rahman et al., 2014). Oral administration of the P. tectorius fruit extract, at 200 and $400 \mathrm{mg} / \mathrm{kg}$, exhibited significant and dose-dependent antidiarrheal effects. The diarrheal episode was reduced by $35 \%$ and $47 \%$, respectively. In addition, the fruit extract significantly inhibited IFA by reducing both the weight and volume of intestinal content and also decreased intestinal transit. Comparable results were obtained with loperamide at $5.0 \mathrm{mg} / \mathrm{kg}$ (standard drug) and with the leaf extract at the same dosage.

In comparison with fruits, more bioactivities have been reported in other plant parts of P. tectorius (Table 2). Leaves possess properties which include antitubercular, antibacterial, anti-inflammatory, hepatoprotective, CNS depressant, antidiarrheal, anticonvulsant, diuretic and neuroprotective activities. Steroids isolated from the stem bark have been reported to be cytotoxic and roots have anti-hyperglycemic and hepatoprotective activities.

\section{CONCLUSION}

Fruits of $A$. altilis and $P$. tectorius are rich in carbohydrates, and are a good source of proteins, vitamins and

Table 2: Bioactivities of other plant parts of Pandanus tectorius

\begin{tabular}{|c|c|}
\hline Plant part and bioactivity & Reference \\
\hline \multicolumn{2}{|l|}{ Leaf } \\
\hline Antitubercular activity of isolated triterpenes and phytosterols & Tan et al. (2008) \\
\hline Growth inhibition of Gram-positive bacteria but not Gram-negative bacteria and yeast & Kumar et al. (2010) \\
\hline Anti-inflammatory effect against carrageenan-induced acute and formalin-induced & Londonkar et al. (2010) \\
\hline chronic paw oedema in mice & Londonkar et al. (2011) \\
\hline Hepatoprotective effect against $\mathrm{CCl}_{4}$-induced liver injury in rats & \\
\hline CNS depressant effects on albino mice & Raju et al. (2011) \\
\hline Antidiarrheal activity against castor oil-induced diarrhoea in rats & Rahman et al. (2014) \\
\hline Anticonvulsant activity against epileptic mice & Adkar et al. (2014) \\
\hline Diuretic activity of extract and isolated squalene & Tan et al. (2014) \\
\hline Neuroprotective activity in mice model with Parkinson's disease & Sitepu et al. (2016) \\
\hline \multicolumn{2}{|l|}{ Stem bark } \\
\hline Cytotoxic steroids isolated from the stem bark & Carver and Truscott (1993); Hoa et al. (2014) \\
\hline \multicolumn{2}{|l|}{ Root } \\
\hline Anti-hyperglycemic activity in alloxan-induced diabetic rats & Madhavan et al. (2008) \\
\hline Protective effects on paracetamol-induced hepatotoxicity in rats & Mishra et al. (2015) \\
\hline Strong antioxidant activity of isolated compounds & Jong and Chau (1998) \\
\hline
\end{tabular}


minerals. Endowed with triterpenes, flavonoids, stilbenes, arylbenzofurans and sterols as chemical constituents, fruits of $A$. altilis possess antioxidant, antimicrobial, anticancer and anti-hyperglycemic properties. With phenolic compounds such as flavonoids and caffeoylquinic acids, fruits of $P$. tectorius possess antioxidant, antibacterial, anti-diabetic, $\alpha$-glucosidase inhibitory and antidiarrheal properties. Although more bioactivities have been reported in other plant parts, there is scientific evidence that the regular consumption of fruits of $A$. altilis and $P$. tectorius by the islanders does have both nutritive and medicinal values. With multiple uses, both species are truly the two cultural icons of Oceania.

\section{Author contributions}

During their expeditions to Oceania, S. Baba (the lead scientist), T. Inoue and M. Kezuka took notes and photographs of $A$. altilis and $P$. tectorius, and related their experiences. Based on available literature, H.T. Chan drafted the review with comments by S. Baba. Being the natural product chemist in the team, Eric Chan (the corresponding author) was responsible for the phytochemistry and pharmacology sections.

\section{REFERENCES}

Adaramoye, O. A. and O. O. Akanni. 2014. Effects of methanol extract of breadfruit (Artocarpus altilis) on atherogenic indices and redox status of cellular system of hypercholesterolemic male rats. Adv. Pharmacol. Sci. 2014: Article ID:605425, 11.

Adaramoye, O. A. and O. O. Akanni. 2016. Modulatory effects of methanol extract of Artocarpus altilis (Moraceae) on cadmium-induced hepatic and renal toxicity in male wistar rats. Pathophysiology. 23: 1-9.

Adewole, S. O. and J. A. O. Ojewole. 2007a. Artocarpus communis Forst. Root bark aqueous extract and streptozotocin-induced ultrastructural and metabolic changes in hepatic tissues of wistar rats. Afr. J. Tradit. Complement. Altern. Med. 4: 397-410.

Adewole, S. O. and J. A. O. Ojewole. 2007b. Hyperglycaemic effect of Artocarpus communis Forst (Moraceae) root bark aqueous extract in wistar rats. Cardiovasc. J. Afr. 18: 221-227.

Adkar, P. P. and V. H. Bhaskar. 2014. Pandanus odoratissimus (Kewda): A review on ethnopharmacology, phytochemistry, and nutritional aspects. Adv. Pharm. Sci. 2014: Article ID:120895, 19.

Adkar, P. P., P. P. Jadhav, S. D. Ambavade, T. T. Shelke and V. H. Bhaskar. 2014. Protective effect of leaf extract of Pandanus odoratissimus Linn on experimental model of epilepsy. Int. J. Nutr. Pharmacol. Neurol. 4: 81-87.

Akanni, O. O., S. E. Owumi and O. A. Adaramoye. 2014. In vitro studies to assess the antioxidative, radical scavenging and arginase inhibitory potentials of extracts from Artocarpus altilis, Ficus exasperata and Kigelia africana. Asian Pac. J. Trop. Biomed. 4: S492-S499.

Altman, L. J. and S. W. Zito. 1976. Sterols and triterpenes from the fruit of Artocarpus altilis. Phytochemistry. 15: 829-830.

Amarasinghe, N. R., L. Jayasinghe, N. Hara and Y. Fujimoto. 2008. Chemical constituents of the fruits of Artocarpus altilis. Biochem. Syst. Ecol. 36: 323-325.
Andriani, Y., N. M. Ramli, D. F. Syamsumir, M. N. I. Kassim, J. Jaafar, N. A. Aziz, L. Marlina, N. S. Musa and H. Mohamad. 2015. Phytochemical analysis, antioxidant, antibacterial and cytotoxicity properties of keys and cores part of Pandanus tectorius fruits. Arab. J. Chem. DOI: 10.1016/j.arabjc.2015.11.003.

Arai, M. A., K. Uchida, S. K. Sadhu, F. Ahmed, T. Koyano, T. Kowithayakorn and M. Ishibashi. 2015. Hedgehog inhibitors from Artocarpus communis and Hyptis suaveolens. Bioorg. Med. Chem. 23: 4150-4154.

Arung, E. T., B. D. Wicaksono, Y. A. Handoko, I. W. Kusuma, D. Yulia and F. Sandra. 2009. Anti-cancer properties of diethyl ether extract of wood from sukun (Artocarpus altilis) in human breast cancer (T47D) cells. Trop. J. Pharm. Res. 8: 317-324.

Baba, S., H. T. Chan and S. Aksornkoae. 2013. Useful Products from Mangrove and other Coastal Plants. ISME Mangrove Educational Book Series No. 3, ISME and ITTO, Japan.

Boonphong, S., A. Baramee, P. Kittakoop and P. Puangsombat. 2007. Antitubercular and antiplasmodial prenylated flavones from the roots of Artocarpus altilis. Chiang Mai J. Sci. 34: 339-344.

Buranajaree, S., P. Donsing, R. Jeenapongsa and J. Viyoch. 2011. Depigmenting action of a nano-emulsion containing heartwood extract of Artocarpus incisus on UVB-induced hyperpigmentation in C57BL/6 mice. J. Cosmet. Sci. 62: 1-14.

Carver, J. A. and R. J. Truscott. 1993. Cytotoxic steroids from the stem barks of Pandanus tectorius. Phytochemistry. 34: 1159-1163.

Deivanai, S. and J. B. Subhash. 2010. Breadfruit (Artocarpus altilis Fosb.) - An underutilized and neglected fruit plant species. Middle-East J. Sci. Res. 6: 418-428.

Dignan, C., B. Burlingame, S. Kumar and W. Aalbersberg. 2004. The Pacific Islands Food Composition Tables, $2^{\text {nd }}$ ed. FAO, Rome, Italy.

Donsing, P., N. Limpeanchob and J. Viyoch. 2008. Evaluation of the effect of Thai breadfruit's heartwood extract on melanogenesisinhibitory and antioxidation activities. J. Cosmet. Sci. 59: 41-48.

Englberger, L., G. C. Marks and M. H. Fitzgerald. 2003a. Insights on food and nutrition in the Federated States of Micronesia: A review of the literature. Public Health Nutr. 6: 5-17.

Englberger, L., M. H. Fitzgerald and G. C. Marks. 2003b. Pacific pandanus fruit: An ethnographic approach to understanding an overlooked source of provitamin A carotenoids. Asia Pac. J. Clin. Nutr. 12: 38-44.

Fakhrudin, N., S. Hastuti, A. Andriani, S. Widyarini and A. Nurrochmad. 2015. Study on the anti-inflammatory activity of Artocarpus altilis leaves extract in mice. Int. J. Pharmacogn. Phytochem. Res. 7: 1080-1085.

Fang, S. C., C. L. Hsu, Y. S. Yu and G. C. Yen. 2008. Cytotoxic effects of new geranyl chalcone derivatives isolated from the leaves of Artocarpus communis in SW 872 human liposarcoma cells. J. Agric. Food Chem. 56: 8859-8868.

Fu, Y. T., C. W. Lee, H. H. Ko and F. L. Yen. 2014. Extracts of Artocarpus communis decrease a-melanocyte stimulating hormone-induced melanogenesis through activation of ERK and JNK signalling pathways. Sci. World J. 2014: Article ID:724314.

Hafid, A. F., R. P. Septiani, L. H. Fabriana, N. Febrianty, D. Ranggaditya and A. Widyawaruyanti. 2016. Antimalarial activity of crude extracts of Artocarpus heterophyllus, Artocarpus altilis and Artocarpus camansi. Asian J. Pharm. Clin. Res. 9: 279-281.

Hakim, A. 2010. Diversity of secondary metabolites from genus Artocarpus (Moraceae). Nusantara Biosci. 2: 146-156.

Hari, A., K. G. Revikumar and D. Divya. 2014. Artocarpus: A review of its phytochemistry and pharmacology. J. Pharm. 9: 7-12.

Hoa, N. T., P. H. Dien and D. N. Quang. 2014. Cytotoxic steroids 
from the stem barks of Pandanus tectorius. Res. J. Phytochem. 8: $52-56$.

Hsu, C. L., F. R. Chang, P. Y. Tseng, Y. F. Chen, M. El-Shazly, Y. C. Du and S. C. Fang. 2012. Geranyl flavonoid derivatives from the fresh leaves of Artocarpus communis and their antiinflammatory activity. Plant Med. 78: 995-1001.

Hsu, C. L., M. H. Shyu, J. A. Lin, G. C. Yen and S. C. Fang. 2011. Cytotoxic effects of geranyl flavonoid derivatives from the fruit of Artocarpus communis in SK-Hep-1 human hepatocellular carcinoma cells. Food Chem. 127: 127-134.

Iwaoka, W., Y. Hagi, K. Umano and T. Shibamoto. 1994. Volatile chemicals identified in fresh and cooked breadfruit. J. Agric. Food Chem. 42: 975-976.

Jagtap, U. B. and V. A. Bapat. 2010. Artocarpus: A review of its traditional uses, phytochemistry and pharmacology. J. Ethnopharmacol. 129: 142-166.

Jalal, T. K., I. A. Ahmed, M. Mikail, L. Momand, S. Draman, M. L. M. Isa, M. S. Rasad, M. N. Omar, M. Ibrahim and R. A. Wahab. 2015. Evaluation of antioxidant, total phenol and flavonoid content and antimicrobial activities of Artocarpus altilis (breadfruit) of underutilized tropical fruit extracts. Appl. Biochem. Biotechnol. 175: 3231-3243.

Jeon, Y. J., S. N. Jung, H. Chang, J. Yun, C. W. Lee, J. Lee, S. Choi, O. Nash, D. C. Han and B. M. Kwon. 2015. Artocarpus altilis (Parkinson) Fosberg extracts and geranyl dihydrochalcone inhibit STAT3 activity in prostate cancer DU145 cells. Phytother. Res. 29: 749-756.

Jones, A. M. P., J. A. Klun, C. L. Cantrell, D. Ragone, K. R. Chauhan, P. N. Brown and S. J. Murch. 2012. Isolation and identification of mosquito (Aedes aegypti) biting deterrent fatty acids from male inflorescences of breadfruit Artocarpus altilis (Parkinson) Fosberg. J. Agric. Food Chem. 60: 3867-3873.

Jones, A. M. P., D. Ragone, N. G. Tavana, D. W. Bernotas and S. J. Murch. 2011. Beyond the bounty: Breadfruit (Artocarpus altilis) for food security and novel foods in the $21^{\text {st }}$ century. Ethnobot. Res. Appl. 9: 129-149.

Jong, T. T. and S. W. Chau. 1998. Antioxidative activities of constituents isolated from Pandanus odoratissimus. Phytochemistry. 49: 2145-2148.

Kuete, V., P. Y. Ango, G. W. Fotso, G. D. W. Kapche, J. P. Dzoyem, A. G. Wouking, B. T. Ngadjui and B. M. Abegaz. 2011. Antimicrobial activities of the methanol extract and compounds from Artocarpus communis (Moraceae). BMC Complement. Altern. Med. 11: 42.

Kumar, D., S. Kumar, S. Kumar, J. Singh, C. Sharma and K. R. Aneja. 2010. Antimicrobial and preliminary phytochemical screening of crude leaf extract of Pandanus odoratissimus L. Pharmacol. Online. 2: 600-610.

Labouisse, J. P. 2016. Ethnobotany of breadfruit in Vanuatu: Review and prospects. Ethnobiol. Lett. 7: 14-23.

Lan, W. C., C. W. Tzeng, C. C. Lin, F. L. Yen and H. H. Ko. 2013. Prenylated flavonoids from Artocarpus altilis: Antioxidant activities and inhibitory effects on melanin production. Phytochemistry. 89: 78-88.

Lim, T. K. 2012. Pandanus tectorius. In: Edible Medicinal and NonMedicinal Plants, Springer Science and Business Media BV, Dordrecht, Heidelberg, London and New York, Pp. 136-146.

Lin, J. A., S. C. Fang, C. H. Wu, S. M. Huang and G. C. Yen. 2011. Antiinflammatory effect of the 5,7,4'-trihydroxy-6-geranylflavanone isolated from the fruit of Artocarpus communis in S100B-induced human monocytes. J. Agric. Food Chem. 59: 105-111.

Lin, K. W., C. H. Liu, H. Y. Tu, H. H. Ko and B. L. Wei. 2009. Antioxidant prenylflavonoids from Artocarpus communis and Artocarpus elasticus. Food Chem. 115: 558-562.

Lin, K. W., B. W. Wang, C. M. Wu, M. H. Yen, B. L. Wei, C. F. Hung and C. N. Lin. 2015. Antioxidant prenylated phenols of Artocarpus plants attenuate ultraviolet radiation-induced damage on human keratinocytes and fibroblasts. Phytochem. Lett. 14: 190-197.

Liu, H., X. Zhang, C. Wu, H. Wu, P. Guo and X. Xu. 2013. Antihyperlipidemic caffeoylquinic acids from the fruits of Pandanus tectorius Soland. J. Appl. Pharm. Sci. 3: 16-19.

Londonkar, R., A. Kamble and V. C. Reddy. 2010. Anti-inflammatory activity of Pandanus odoratissimus extract. Int. J. Pharmacol. 6: 311-314.

Londonkar, R. and A. Kamble. 2011. Hepatotoxic and in vivo antioxidant potential of Pandanus odoratissimus against carbon tetrachloride induced liver injury in rats. Orient. Pharm. Exp. Med. 11: 229-234.

Lotulung, P. D., S. Fajriah, M. Hanafi and E. Filaila. 2008. Identification of cytotoxic compound from Artocarpus communis leaves against P-388 cells. Pak. J. Biol. Sci. 11: 2517-2520.

Madhavan, V., J. C. Nagar, A. Murali, R. Mythreyi and S. N. Yoganarasimhan. 2008. The anti-hyperglycemic activity of alcoholic and aqueous extracts of Pandanus odoratissimus L. roots in alloxan induced diabetic rats. Pharmacol. Online. 2: $600-610$.

Mai, D. T., T. D. Le, T. P. Nguyen, N. M. Phan, H. A. Nguyen, T. T. P. Nguyen and L. Q. Tran. 2015. A new aldehyde compound from the fruit of Pandanus tectorius Parkinson ex Du Roi. Nat. Prod. Res. 29: 1437-1441.

Mishra, G., R. L. Khosa, P. Singh and K. K. Jha. 2015. Hepatoprotective potential of ethanolic extract of Pandanus odoratissimus root against paracetamol-induced hepatotoxicity in rats. J. Pharm. Bioallied Sci. 7: 45-48.

Mohanty, M. and C. Pradhan. 2015. A review on phytochemistry, bio-efficacy, medicinal and ethno-pharmaceutical importance of Artocarpus altilis. Int. J. Pharm. Pharm. Res. 3: 219-231.

Mozef, T., C. Risdian, E. Y. Sukandar and A. A. Soemardji. 2015. Bioactivity of ethyl acetate fraction from the leaves of 'Sukun' Artocarpus altilis (Parkinson) Fosberg in preventing atherosclerosis. Proc. Chem. 16: 106-112.

Nguyen, M. T., N. T. Nguyen, K. D. Nguyen, H. T. Dau, H. X. Nguyen, P. H. Dang, T. M. Le, T. H. Phan, A. H. Tran, B. D. Nguyen and J. Y. Ueda. 2014. Geranyl dihydrochalcones from Artocarpus altilis and their antiausteric activity. Plant Med. 1: 1-4.

Nwokocha, C. R., D. U. Owu, M. McLaren, J. Murray, R. Delgoda, K. Thaxter, G. McCalla and L. Young. 2012. Possible mechanisms of action of the aqueous extract of Artocarpus altilis (breadfruit) leaves in producing hypotension in normotensive sprague-dawley rats. Pharm. Biol. 50: 1096-1102.

Pradhan, C. H., M. O. Mohanty, A. B. Rout, A. B. Das, K. B. Satapathy and H. K. Patra. 2013. Phytoconstituent screening and comparative assessment of antimicrobial potentiality of Artocarpus altilis fruit extracts. Int. J. Pharm. Pharm. Sci. 5: 840-843.

Ragone, D. and C. G. Cavaletto. 2006. Sensory evaluation of fruit quality and nutritional composition of 20 breadfruit (Artocarpus, Moraceae) cultivars. Econ. Bot. 60: 335-346.

Ragone, D. 2006. Artocarpus altilis (breadfruit). In: C. R. Elevitch (Ed.), Species Profiles for Pacific Island Agroforestry, Version 2.1. Permanent Agriculture Resources, Holualoa, Hawaii, Pp. 1-17.

Ragone, D. 2011. Farm and forestry production and marketing profile for breadfruit (Artocarpus altilis). In: C. R. Elevitch (Ed.), 
Specialty Crops for Pacific Island Agroforestry, Permanent Agriculture Resources, Holualoa, Hawaii. Available from: http:// www.agroforestry.net/scps. [Last accessed on 2015 Dec 10].

Rahman, M. K., M. F. Islam, S. Barua, M. M. Rahman and M. A. Sayeed. 2014. Comparative study of antidiarrheal activity of methanol extracts from leaf and fruit of Pandanus odoratissimus Linn. Orient. Pharm. Exp. Med. 14: 363-367.

Raju, S., N. V. Subbaiah, K. S. Reddy, A. Das and K. B. Murugan. 2011. Potential of Pandanus odoratissimus as a CNS depressant in Swiss albino mice. Braz. J. Pharm. Sci. 47: 629-634.

Rao, G. V., M. Gopalakrishnan, M. S. L. Madhavi, T. Mukhopadhyay, J. Thanusu and M. R. Ezhilarasi. 2013. Dendrite elongation inhibitor from Artocarpus altilis Parkinson. J. Pharm. Res. 7: 358-361.

Safitri, D., E. Y. Sukandar and S. Rachmamaryam. 2016. Effect of ethanolic extract of breadfruit Artocarpus altilis (Parkinson) Fosberg) leaves on ameliorating renal function of rat. Asian J. Pharm. Clin. Res. 9: 215-218.

Sairam, S. and A. Urooj. 2013. Artocarpus altilis - Mode of antihyperglycemic activity: Elucidation by suitable in-vitro and exvivo techniques. Int. J. Pharm. Sci. Res. 4: 3013-3019.

Shimizu, K., M. Fukuda, R. Kondo and K. Sakai. 2000. The 5a-reductase inhibitory components from heartwood of Artocarpus incisus: Structure-activity investigations. Plant Med. 66: 16-19.

Shimizu, K., R. Kondo, K. Sakai, S. H. Lee and H. Sato. 1998. The inhibitory components from Artocarpus incisus on melanin biosynthesis. Plant Med. 64: 408-412.

Sikarwar, M. S., B. J. Hui, K. Subramaniam, B. D. Valeisamy, L. K. Yean and K. Balaji. 2014. A review on Artocarpus altilis (Parkinson) Fosberg (breadfruit). J. Appl. Pharm. Sci. 4: 91-97.

Sitepu, E. C., R. Adji, A. K. Tedja and S. Simanjaya. 2016. Neuroprotective effect of ethanolic extract of Pandanus odoratissimus L. in paraquat mice model of Parkinson's disease. Parkinson Relat. Disord. 22: e187.

SPC. 2001. The Food We Eat, Secretariat of the Pacific Community, Noumea, New Caledonia.

Tan, M. A., M. T. E. Ebrada and M. G. Nonato. 2014. Diuretic activity of Pandanus tectorius (Pandanaceae). Der Pharm. Chem. 6: 423-426.

Tan, M. A., H. Takayama, N. Aimi, M. Kitajima, S. G. Franzblau and M. G. Nonato. 2008. Antitubercular triterpenes and phytosterols from Pandanus tectorius Soland. var. laevis. J. Nat. Med. 62: 232-235.

The Plant List. 2013a. Artocarpus. Database. Available from: http:// www.theplantlist.org. [Last accessed on 2016 Jan 02].

The Plant List. 2013b. Pandanus. Database. Available from: http:// www.theplantlist.org. [Last accessed on 2016 Jan 02].

Thomson, L. A., L. Englberger, L. Guarino, R. R. Thaman and C. R. Elevitch. 2006. Pandanus tectorius (pandanus). In: C. R. Elevitch (Ed.), Species Profiles for Pacific Island Agroforestry, Version 1.1. Permanent Agriculture Resources, Holualoa, Hawaii, Pp. 1-29.

Tiraravesit, N., S. Yakaew, R. Rukchay, W. Luangbudnark, C. Viennet, P. Humbert and J. Viyoch. 2015. Artocarpus altilis heartwood extract protects skin against UVB in vitro and in vivo.
J. Ethnopharmacol. 175: 153-162.

Turi, C. E., Y. Liu, D. Ragone and S. J. Murch. 2015. Breadfruit (Artocarpus altilis and hybrids): A traditional crop with the potential to prevent hunger and mitigate diabetes in Oceania. Trends Food Sci. Technol. 45: 264-272.

Tzeng, C. W., F. L. Yen, L. T. Lin, C W. Lee, M. H. Yen, W. S. Tzeng and C. C. Lin. 2014. Antihepatoma activity of Artocarpus communis is higher in fractions with high artocarpin content. Sci. World J. 2014: Article ID:978525, 1-8.

Vahirua-Lechat, I., C. Menut, B. Roig, J. M. Bessiere and G. Lamaty. 1996. Isoprene related esters, significant components of Pandanus tectorius. Phytochemistry. 43: 1277-1279.

Walter, A. and V. Lebot. 2007. Gardens of Oceania. ACIAR Monograph No. 122, Australian Centre for International Agricultural Research, Canberra.

Walter, A. and V. Sam. 2002. Fruits of Oceania. ACIAR Monograph No. 85, Australian Centre for International Agricultural Research, Canberra.

Wang, Y., T. Deng, L. Lin, Y. Pan and X. Zheng. 2006. Bioassayguided isolation of anti-atherosclerotic phytochemicals from Artocarpus altilis. Phytother. Res. 20: 1052-1055.

Wang, Y. Y., Q. C. Wang and H. M. Zhong. 2011. Analysis on alcohol essential oil components of pandanus fruit. J. Qingdao Univ. Sci. Technol 2011-04.

Wei, B. L., J. R. Weng, P. H. Chiu, C. F. Hung, J. P. Wang and C. N. Lin. 2005. Anti-inflammatory flavonoids from Artocarpus heterophyllus and Artocarpus communis. J. Agric. Food Chem. 53: 3867-3871.

Weng, J. R., S. C. Chan, Y. H. Lu, H. C. Lin, H. H. Ko and C. N. Lin. 2006. Antiplatelet prenylflavonoids from Artocarpus communis. Phytochemistry. 67: 824-829.

Wong, S. K., Y. Y. Lim, S. K. Ling and E. W. C. Chan. 2014. Caffeoylquinic acids in leaves of selected Apocynaceae species: Their isolation and content. Pharmacogn. Res. 6: 67-72.

Wu, C., X. Zhang, X. Zhang, H. Luan, G. Sun, X. Sun, X. Wang, P. Guo and X. Xu. 2014. The caffeoylquinic acid-rich Pandanus tectorius fruit extract increases insulin sensitivity and regulates hepatic glucose and lipid metabolism in diabetic $\mathrm{db} / \mathrm{db}$ mice. J. Nutr. Biochem. 25: 412-419.

Wu, C., H. Luan, S. Wang, X. Zhang, H. Liu and P. Guo. 2015. Pandanus tectorius derived caffeoylquinic acids inhibit lipid accumulation in HepG2 hepatoma cells through regulation of gene expression involved in lipid metabolism. Acta Pharm. Sinica 50: 278-283.

Zhang, X., P. Guo, G. Sun, S. Chen, M. Yang, N. Fu, H. Wu and X. Xu. 2012. Phenolic compounds and flavonoids from the fruits of Pandanus tectorius Soland. J. Med. Plants Res. 6: 26222626.

Zhang, X., H. Wu, C. Wu, P. Guo, X. Xu and M. Yang. 2013a. Pandanusphenol A and B: Two new phenolic compounds from the fruits of Pandanus tectorius Soland. Rec. Nat. Prod. 7: 359362.

Zhang, X., C. Wu, H. Wu, L. Sheng, Y. Su, X. Zhang, H. Luan, G. Sun, X. Sun, Y. Tian and Y. Ji. 2013b. Anti-hyperlipidemic effects and potential mechanisms of action of the caffeoylquinic acid-rich Pandanus tectorius fruit extract in hamsters fed a high fat-diet. PLoS One 8: e61922. 